\title{
The use of picture series on Instagram to improve students' writing in EFL writing class
}

\author{
Dila Anggita ${ }^{1}$, Mahpul $^{2}$, Fajar Riyantika ${ }^{3}$ \\ Universitas Lampung, Jl. Prof. Dr. Sumantri Brojonegoro, Rajabasa, Bandar Lampung ${ }^{1,2,3}$ \\ Correspondence: dilanggita@yahoo.com
}

\begin{abstract}
Instagram has been used as the medium to upload photos, e.g. picture series. The current research was intended to find out I) whether picture series on Instagram could facilitate students to improve their writing achievement, II) students' perceptions of the use picture series. The design of the research was mixed quantitative and qualitative approaches. The subjects of the research were 31 students of thefirstgradeofSMANegeri2BandarLampung. The data were collected through the writing tests (pre and post-tests) and questionnaires. The results showed that (i) there was a statistically significant improvement of the students' writing achievement after the students were taught using picture series on Instagram with the significant 0.05 . (ii) There were positive perceptions of the use of picture series on Instagram. This suggests that picture series on Instagram facilitates students to improve students' writing achievement.
\end{abstract}

Keywords: picture series, Instagram, writing achievement, EFL class.

\section{INTRODUCTION}

This research investigates the differences of students' writing achievement after being taught using picture series on Instagram and to describe the students' responses toward the use of picture series on Instagram to improve the students' writing achievement.Masitoh and Suprijadi (2015) writing skill is regarded as the most difficult and complex language skill because it requires extent of perception and involves thinking process extensively. In addition, they stated most Indonesian students face some difficulties in writing, they have to consider the grammar to make their writing understandable. Briefly, writing needs some consideration to avoid misunderstanding between the readers.

According to Caroll (1990) a good writing is something they believe they will never be able to achieve, because they not only identify good writing with proper spelling and grammar, but they are governed by the self-serving and false notion that they can not learn how to spell correctly or how to construct grammatically correct sentences. Therefore, a good writer deal with some difficulties in making a good writing.

Harmer (2004) stated writing encourage students to focus on accurate language use and, because they think as they write, it will provoke language development as they resolve problems which the writing puts into their minds. However, most of EFL students face some difficulties in writing such as do not know how to develop their ideas clearly, how to choose appropriate words, how to organize their ideas, and how to arrange the idea into cohesive paragraphs.

According to curriculum 2013 for senior high school, writing is one of the competencies that must be developed in every levels. Students are expected to be able to produce an English text. Therefore, to ensure that the teaching of EFL writing is going in the right direction, English teachers must be aware of recent EFL writing theories and practices. Since writing is the most complex task in EFL Class, the use of media makes English language teaching more effective and better. Briefly, teaching using media can help teachers easy to teach and make students become interested and understand to learn English.

In order to develop EFL students' writing achievement, a teacher can use an up-to-date media that make students enjoy the learning process. Cahyono \& Mutiaraningrum (2015) stated the development of 
Information and Communication Technology (ICT), especially the internet, has affected how the students learn, how they interact with teachers and other students, and how they deal with various aspects of their daily life. They believed the internet can stimulate collaborations and thinking skills. In brief, teachers and students can utilize the internet to create a meaningful learning media.

Nowadays, technology is more sophisticated and modern. There are many types of new technology. One of them is smartphone. People use smartphones for anything including a medium for learning English. There are many applications that can be used to help students and teachers, one of which is Instagram. Instagram is a medium that permitted the user to explore more their social in the network by sharing with each other such as, content, news, photo, etc. Using Instagram as a learning media is an easy way to help students learn about descriptive text. In Instagram, students can share from 1 to 10 slide images that can be referred to as a picture series. Then students can provide an explanation about people, thing, or place that relates to the generic structure of descriptive text.

Social media platforms are regarded as powerful tools for teaching and learning practices through their nature of openness, interactivity, and sociability (Manca \& Ranieri, 2016). Shazali, Shamsudin, Yunus (2019), stated Instagram can create a fun and meaningful learning environment for the students as they are enjoying using Instagram in doing school tasks. Besides, Alfiyatun \& Muntaha (2018) elaborated that the use of Instagram as a medium can affect a higher score to the students compared with the students who were taught with the only pictures.

Some researchers stated that writing the most crucial skill other than skills. Masitoh and Suprijadi (2015) writing skill is regarded as the most difficult and complex language skill because it requires extent of perception and involves thinking process extensively. According to Idrus (2003), Teaching writing requires the elements of writing including grammar, sentence organization, vocabulary, and mechanics. In another word, in teaching writing the teacher should guide the students not only to write sentence but also to organize their ideas into written form properly.In addition, they stated most Indonesian students face some difficulties in writing, they have to consider the grammar to make their writing understandable. Briefly, writing needs some consideration to avoid misunderstanding between the readers.

There are five previous studies underlie this present research. The first was conducted by Amelia and Triyanti (2020) about The Use Of Instagram To Develop Students' Writing Ability. The objective of their research is to find out whether Instagram is effective to teach writing for the tenth grade students of SMA Negeri 3 Bekasi in academic year 2019/2020. The methodology of this research was Quasi Experimental Method, and the design was randomized post-test only control group design. In this research, there was a significant difference of Instagram on students' writing ability at SMAN 3 Bekasi. The result of this research presented that there is significance (Sig.) score of T-test 0.000 is lower than $(<) 0.05$. Thus, it can be concluded that Instagram helped the students to develop their writing, and also, it can ease the teaching and learning process. The second research was conducted by Irmalia, Musyarofah, and Sulistyaningsih (2018) about Teaching Writing Descriptive Text Using Instagram. The sample of this research was 31 students of tenth grade students of MIPA 3 SMA Muhammadiyah 3 Tulangan in 2017-2018 academic year. Based on the result, Instagram can be used as a learning media in teaching writing about descriptive text. The third research was conducted by Apsari (2017) about The Use of Picture Series in Teaching Writing Recount Text. In collecting the data, the researcher used observation and interview. The results of the study presented that there is some improvement on process of writing and vocabulary.The fourth research was conducted by Pasaribu (2017) about The Students' Perception on the Use of Picture to Improve Descriptive Paragraph Writing at Christian University of Indonesia. It conducted to examine the students' perception on the use of picture in writing descriptive paragraph and to investigate whether the students were interested in the use of picture in writing descriptive paragraph. The fifth research was conducted by Shazali, Shamsudin, and Yunus (2019) about Instagram: A Platform to Develop Student's Writing Ability. They stated that Instagram has an impact on students' vocabulary and grammar accuracy. Moreover, students satisfied applying Instagram as their learning tool. While this present research will 
focus on the differences of students' writing achievement after being taught using picture series on Instagram. Moreover, this research also describes the students' responses toward the use of picture series on Instagram to improve the students' writing achievement.

\section{METHODS}

This research used quantitative and qualitative method. Quantitative research which involved collecting and analyzing numerical data. The research was intended to find out whether there aredifferencesof students' writing achievement after being taught using picture series on Instagram picture series on Instagram in teaching writing about descriptive text.

The design can be presented as follows:

\section{T1 X T2}

T1 : Pre-test

T2 : Post-test

$\mathrm{X}$ : Treatment (teaching process)

Meanwhile, this research also used qualitative method to know students' perception about teaching writing using picture series on Instagram. Thus, the researcher gave a questionnaire to the students after the post-test. The researcher used open-ended questionnaire which each question allowed the student as the respondent to create answers based on their experience. They also have to explain their reasons to confirm their choice. This method help the researcher to categorize the responses easier and clearer to be analyzed.

The researcher conducted the research by using one class. The subject of this research was one class the first grade students of SMA Negeri 2 Bandar Lampung in the academic year 2020/2021 that is X MIPA 1 which consisted of 31 students. There were two instuments to gain the data. The first was writing test. In the pre-test and post-test, the students were asked to make a descriptive text using picture series on Instagram about a country that they want to visit. The second instrument was questionnaire. It was distributed to all research subjects after they got a treatment how to write a descriptive text through picture series on Instagram. It was used to find out whether picture series on Instagram was effective to use for teaching writing. The researcher distributed the question items using google form.

The researcher used The Inter-Rater Reliability method to measure the reliability. It was assessed by two raters in which both raters use same criteria for scoring the students' writing skill test.To analyze the validity of writing assessment, the researcher considered it from the content validity. In this research, content validity was used to find out whether the content of the test was fully representative to be valid assessment instrument of what it was supposed to be measured. To guide the analysis, the researcher used a writing scoring rubric by Jacobs cited in Reyhan (2012). The scoring rubric is as follows:
1. Content
$: 30 \%$

2. Organization $: 20 \%$

3. Vocabulary : $20 \%$

4. Languange $: 25 \%$ 
5. Mechanic :5\%

TOTAL $: 100 \%$

1)Content

It refers to how writer develop the ideas logically.

2)Organization

Itrefers to how writer arrange the ideas sequentially including introduction, body, and conclusion.

3)Vocabulary

It refers to how writer choose an appropriate word.

4)Languange

It refers to syntactical and grammatical structures.

5)Mechanic

It refers to capitalization, spelling, and punctuation.

The procedure of the research was conducted as follows:

1. Giving pre-test

In the beginning of the research, the students as the sample of the research would be given a task to know their prior knowledge about writing a descriptive text.

2. Giving treatment

The sample of the research was taught about descriptive text through picture series on Instagram. The treatment was done three times.

\section{Observing}

While doing the treatment, an observation was done by the researcher to find out students' difficulties in writing a descriptive text.

4. Giving post test

Post test was aimed to evaluate the students' writing skill after getting the treatment.

5. Distributing questionnaire

Students would be given a questionnaire using google form about students' difficulties and problem in writing a descriptive text after being taught using picture series on Instagram and their responses toward the media.

6. Scoring students' writing test

The score would be used the researcher to see the improvement students' writing achievement. 


\section{Analyzing the data}

After all the data were collected, the students' scores both from the pre-test and the post-test were analyzed to find out the answers of the research questions.

\section{RESULTS AND DISCUSSIONS}

This chapter reported the result of this research which covers the results of students' writing test in terms of content, organization, vocabulary, language use, and mechanics. Also the results of students' responses after teaching toward picture series on Instagram. There were two raters who gave the score on students' writing achievement. The raters focused on five aspects of writing (Jacobs cited in Reyhan, 2012). They are content, organization, language use, vocabulary, and mechanics. The results of pre-test are listed as follows:

Table 3.1 Distribution of Pre-Test Score

\begin{tabular}{|l|l|l|l|}
\hline No. & $\begin{array}{l}\text { Students' } \\
\text { score interval }\end{array}$ & Frequencies & Percentage \\
\hline 1 & $60-64.5$ & 7 & $22.5 \%$ \\
\hline 2 & $65-69.5$ & 21 & $67.8 \%$ \\
\hline 3 & $70-74.5$ & 3 & $9.7 \%$ \\
\hline \multicolumn{2}{|l}{ Total } & 31 & $100 \%$ \\
\hline \multicolumn{2}{|l}{ Mean score } & 66 & \\
\hline
\end{tabular}

The table 4.1 shows that the students still gained low quality of writing descriptive text before getting treatment. It was evidenced by the mean score of pre-test was 66 with the highest score was 73.5 and the lowest score was 61.5.

After analyzing the pre-test result, the researcher composed the post test result. Same as the pre-test, the researcher and the English teacher as the raters would use the same criteria to assess the students' writing for the post-test. The results of post-test are listed as follows:

Table 3.2 Distribution of Post-Test Score

\begin{tabular}{|l|l|l|l|}
\hline No. & $\begin{array}{l}\text { Students' } \\
\text { score interval }\end{array}$ & Frequencies & Percentage \\
\hline 1 & $75-79.5$ & 8 & $26 \%$ \\
\hline 2 & $80-84.5$ & 18 & $58 \%$ \\
\hline 3 & $85-89.5$ & 5 & $16 \%$ \\
\hline \multicolumn{2}{|l|}{ Total } & 31 & $100 \%$ \\
\hline \multicolumn{2}{|l}{ Mean } & 81,66 & \\
\hline
\end{tabular}

The table 4.2shows that there is an improvement on students' score after being the treatment. It was evidenced by the mean score of post-test was 81.66 with the highest score was 89 and the lowest score was 76.5. 
The researcher also analyzed the percentage of each items in the quetionnaire, which was as the students' perception toward the implementation of picture series on Instagram for teaching writing. There were 31 students participating as subjects of this research who also filled the questionnaire given by the researcher using google form. The question items of this research are listed as follows:

1. According to you, is learning writing a descriptive text using picture series on Instagram EASY or DIFFICULT?

2. According to you, is learning writing a descriptive text using picture series on Instagram make you RELAX or NOT RELAX?

3. According to you, do you feel SUCCESSFUL or FAIL in learning writing a descriptive text using picture series on Instagram?

4. According to you, is learning writing a descriptive text using picture series on Instagram INTERESTING or NOT INTERESTING?

5. According to you, are you MOTIVATED (want to do learning like this) or NOT MOTIVATED?

6. According to you, is learning writing a descriptive text using picture series on Instagram HELP you in improving your skills: (you can choose more than 1)

a. Vocabulary mastery

b. Content development

c. Grammar understanding

d. Mastery of writing format

e. Understanding of the arrangement between sentences (organization)

After distributing the questionnaire, the researcher analyzed the results using chart to categorize the students' responses of each items. The analysis could be seen as follows:

1. Question item one

\section{Chart 3.1}

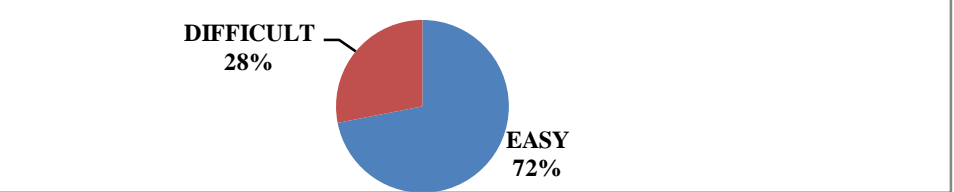

2. Question item two

\begin{tabular}{|c|c|}
\hline Chart 3.2 & $\begin{array}{l}\text { NOT } \\
\text { RELAX } \\
10 \%\end{array}$ \\
\hline
\end{tabular}


3. Question item three

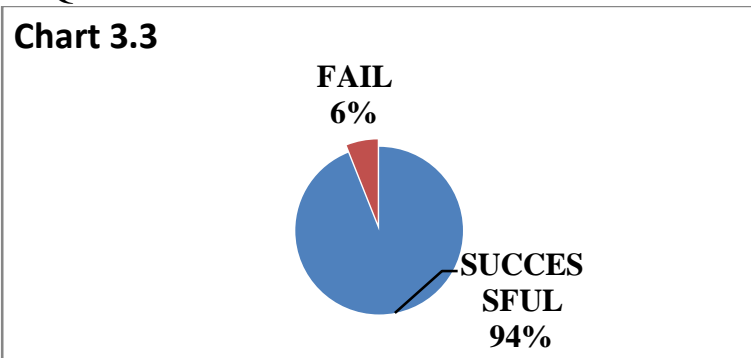

4. Question item four

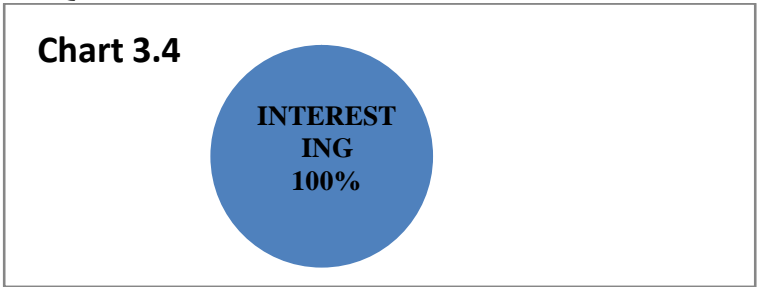

5. Question item five

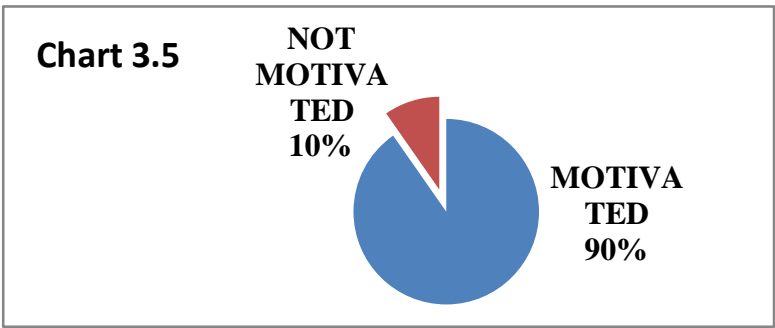

6. Question item six

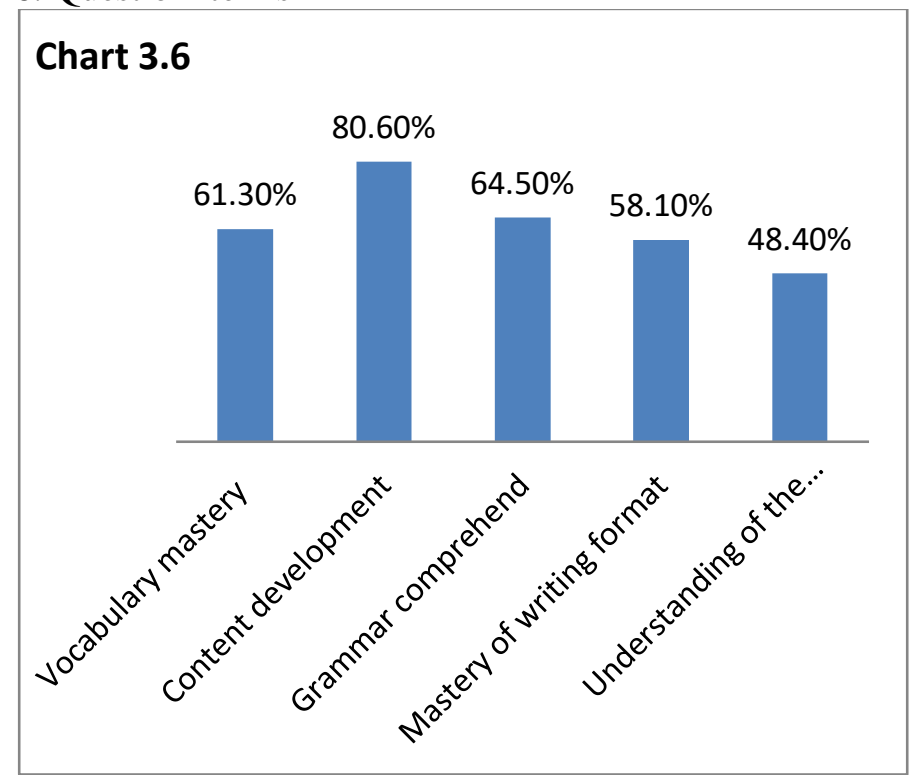




\section{Discussions}

From the result, the researcher found significant differences of students' writing achievement after they got treatment for three times. It can be seen from the difference of mean in the pre-test and post-test. The mean score for pre-test is 66 and post-test is 81.6.The result in the pre-test can be reported as follows:

\section{Content}

In the pre-test, the students writing productions did not have detailed, and only slightly represent the pictures. Some students described the country in general. They did not explain in detail and did not provide specific information. It was because they did not know how to develop their idea. As an example:

"This museum is one of the oldest museums in the world and in this museum houses paintings, artifacts, sculptures from ancient Greece onwards and the State Hermitage Museum has been around since 1764 and has been open to the public since 1852."

\section{Organization}

Since their content was too general, some students could not organize their ideas properly. Consequently, their writing was not balanced for each paragraph or even sentences. In addition, they did not use sufficient expression to opinion and the logical arrangement in order to clarify their ideas.

\section{Vocabulary}

In the pre-test, students used confusing words that might cause misunderstanding. The choice of words used to express the meaning properly is considered improper. As an example:

"5. Alexander Garden. This Park is the first urban park in Russia. The garden is divided into three separate gardens of flowers where it is very beautiful and varied."

\section{Language use}

This aspect focused on the grammatical correct and syntactic pattern on separating, combining, and grouping ideas in words, phrases, clauses, and sentences to build up logical relationship in paragraph. Some students made mistakes in the use of tenses. In making a compound sentence, they put inappropriate conjuction. As an example:

"Here you can also do various activities such as hockey, fishing, rock climbing etc. here too we can enjoy the scenery and various places to take pictures."

\section{Mechanics}

In this aspect, students made mistakes in punctuation, capitalization, and spaces. In some cases, they wrote names of places in all lowercase. They paid less attention to the spacing and punctuation used.

Then, those five aspects of writing improved in the post-test. It happened after they saw and discussed it. The results can be reported as follows:

\section{Content}

After getting the treatments, the students have known to develop and arrange the ideas of their paragraph well. Besides, they got better in making introduction to identify their description. They have known how to simplify the identification to open their writing. As an example: 
"First, I want to visit the Eiffel tower. Eiffel tower is a wrought-iron lattice toweron the Champ de Mars in Paris, France. The height of this tower is 300-324 meter. I want to visit Eiffel Tower because it's so beautiful especially during the night. The beautiful lights will lit around the tower."

\section{Organization}

The researcher found that the students had used conjunctive sentences in their paragraphs. There were less jumping sentence and paragraph. They could make their writing balance for each paragraph. Then, in giving their description have arranged in the logical description. As an example:

"First of all, I want to visit Santorini. It is an island in the southern Aegean Sea, about 200km southeast from Greece. Santorini is the diamond of the Aegean. One of the most famous places to visit in Greece."

\section{Vocabulary}

In the post-test draft, the students could make their ideas simple directly. They elaborated their ideas clearly and used simple vocabulary suit to the meaning that they want to convey. As an example:

"Japan, the country full of beautiful sakura trees, is a country that I want to visit. There are many places I want to visit and many foods I want to eat in Japan."

\section{Language use}

In the post-test, this aspect was also getting better. The students made a better writing with logical paragraphs. They used better phrase and clause in conveying their ideas into paragraphs. As an example:

"I want to visit this building because it has a deep history."

\section{Mechanics}

In this aspect, the students have known how to use a proper punctuation. This can be seen from their posttest draft, they paid more attention in the use of punctuation like comma, semi colon, and colon. As an example:

"Mallorca or Majorca, the largest island in the Balearic Islands, is surrounded by the sparkling water of the Mediterranean."

The researcher found some mistakes in their writing, which might be influenced by lack of attention. Furthermore, from the content, some ideas were too general. Besides, the samples used fewer conjunction to connect their ideas.

On the other hand, after getting the treatment, the students' writing were improved. It was proven by their writing quality. they made errors less than what they had done in the pre-test. They elaborated their ideas clearly and related to the topic. They used more appropriate conjuctions. Within the treatments, the students were asked to read and comment their friends writing based on the 5 aspects of writing. Thus, they could consider their friends' comment.

This research is line with Irmalia, Musyarofah, and Sulistyaningsih's research (2018), they also used one class as the research sample. They stated that Instagram could make the students' writing achievement improved. It happened because the students are more enjoy, focus, enthusiastic with the media. Nevertheless, the researcher utilized one of Instagram's newest features that can be said picture series because Instagram users can share more than one picture. This research was strengthened by a statement from Shazali, Shamsudin, \& and Yunus (2019). They concluded that Instagram can be an effective media 
for developing students' writing quality. Same as this previous research, the students' writing quality developed during the learning process.

From the questionnaire results, it was found that the percentage of each items showed that mostly students agree with the use of picture series on Instagram in their writing class. Chart 4.1 shows $72 \%$ of 31 students thought that writing descriptive text using picture series on Instagram was easy and $28 \%$ of 31 students stated it was difficult. The chart 4.2 shows $90 \%$ of 31 students stated that writing descriptive text using picture series on Instagram was relax and $10 \%$ of 31 students stated it was not relax.Based on chart 4.3 , it can be concluded that picture series on Instagram can improve the students' writing achievement. There were $94 \%$ of 31 students stated it was successful to increase their writing. There were more students like using picture series on Instagram as a media. It was proven by the students' statementson chart 4.4, 100\% students were interested in using picture series on Instagram for their writing class. Then, chart 4.5 shows there were $90 \%$ of 31 students were motivated to learn using picture series on Instagram for their writing class. Only $10 \%$ of 31 students were not motivated for some reasons. In addition, on chart 4.6, students' stated that they have improved on 5 aspects of writing in which content development got the highest percentage that was $80.60 \%$. It happened because they could revise the ideas properly. While, understanding of the arrangement between sentences (organization) was the lowest percentage. It was $48.40 \%$. They claimed they did not know how to put some ideas sequentially.

This finding is in line with the previous research of Anggraeni (2017) who found that most students gave positive response toward using Instagram in writing class. Similar to the previous research, this research used open-ended questionnaire to find out the second research question. The researcher stated that one of the benefits of Instagram was easy to use in any time and situation. This means, Instagram helps the students to write better.

\section{CONCLUSIONS}

In line to the findings that the researcher found after conducting the research, the researcher draws several conclusions. Firstly, from the Sig. score and 31 students' perceptions that participated in this research, it is clear that picture series on Instagram can effectively improve students' writing achievement. It plays a significant role in helping students to elaborate their ideas to make their writing become well-organized that are shown based on the students' writing scores and their responses. Besides, picture series on Instagram provides a meaningful and fun learning experience for the students.

Furthermore, based on the percentage on the result charts, students like to use picture series on Instagram in writing class because they can see many examples of their friends' work and they can give or receive comments from their friends directly on the comment section. Other than that, in this modern era, the teacher can motivate the students to utilize their social media appropriately to help them learning.

\section{REFERENCES}

Alfiyatun, A., \& Muntaha, M. (2018). The effectiveness of instagram captions to teach writing (an experimental research on the tenth grade students of SMA Muhammadiyah 1 Karanganyar in academic year 2017/2018) (doctoral dissertation, IAIN Surakarta). 
Anggraeni, C. W. (2017, April). Students perspectives toward the use of instagram in writing class.English language and literature international conference (ELLIC) proceedings (vol. 1, pp. 68-74).

Apsari, Y. (2017). The use of picture series in teaching writing recount text. Eltin journal, journal of English language teaching in Indonesia, 5(2), 51-56.

Ariningsih, D. (2010). The effectiveness of using picture series to improve the students' writing skill viewed from their learning motivation (an experimental study in the seventh grade of SMPN 1 Tanjunganom Nganjuk in the academic year 2008/2009) (doctoral dissertation, UNS (Sebelas Maret University)).

Cahyono, B. Y., \& Mutiaraningrum, I. (2016). Indonesian efl teachers' familiarity with and opinion on the internet-based teaching of writing. English language teaching, 9(1), 199-208.

Caroll, R. T. (1990). Students success guide--writing skills. Skeptic's dictionary.

Friedman, L. W., \& Friedman, H. (2013). Using social media technologies to enhance online learning. Journal of educators online, 10(1), 1-22.

Ghozali, I. (2006). Ghozali, Imam. 2006. Aplikasi analisis multivariate dengan program spss. Semarang: Badan penerbit UNDIP. Analisis multivariate dengan program SPSS.

Harmer, J. (2004). How to teach writing. Edinburgh Gate.

Hatch, E., \& Farhady, H. (1982). Research design and statistics for applied linguistics.

Hidayati, K. H. (2018). Teaching writing to EFL learners: An investigation of challenges confronted by Indonesian teachers. Langkawi: Journal of the association for Arabic and English, 4(1), 21-31.

Hilliard, R. L. (2014). Writing for television, radio, and new media. Nelson education.

Indah, R. (2018). The influence of think-talk-write technique by using picture to improve students'descriptive writing at the first grade of SMA Al Azhar 3 Bandar Lampung.

Irmalia, T. L., Musyarofah, L., and Sulistyaningsih. (2018). Teaching writing descriptive text using instagram. Repository STKIP PGRI Sidoarjo. 
Iwai, Yuko. (2011). The effects of metacognitive reading strategies: Pedagogical implications for efl/esl teachers.Reading matrix journal.11 (2).

Jati, S. O. (2018). The effect of teacher's indirect feedback on descriptive $\quad$ writing at SMA AlAzhar 3 Bandar Lampung.

Manca, S., \& Ranieri, M. (2016). Facebook and the others. Potentials and obstacles of social media for teaching in higher education. Computers \& Education, 95, 216-230.

Masitoh, S., \& Suprijadi, D. (2015). Improving students' ability in writing descriptive text using genre based approach (gba) at the eight grade students of SMP Islam Terpadu Fitrah Insani.Eltin journal, journal of English language teaching in Indonesia, 3(1).

Nurdiansyah, A., \& Abdulrahman, T. R. (2020). The use of instagram to develop students'writing ability. Akademika, 9 (01), 97-107.

Nunan, D. (2003). Practical english language teaching. New York: Mc Graw Hill.

Nurweni, a. (2018). English teaching assessment; artificial and authentic assessment. Graha Ilmu. Yogyakarta.

Pasaribu, E. T. (2012). The students's perception on the use of picture to improve descriptive paragraph writing at Christian university of Indonesia,Journal of english teaching, 3(2), 134-142.

Reyhan, A. (2012). The use of guided writing and sequences of pictures as teaching technique to enhance the ability of writing narrative of studentsin“different English course". Organization, 20(18), 1714.

Ruantika, R. A. (2019). The use of modified jigsaw technique to improve tenth grade students' writingability. Doctoraldissertation, University of Lampung.

Setiyadi, B., Sukirlan, M., Mahpul. (2016). How successful learners employ learning strategies in an efl setting in the Indonesian context.English language teaching, 9(8), 28-38.

Setiyadi, B. (2018). Metode penelitian untuk pengajaran bahasa asing: Pendekatan kuantitatif dan kualitatif. Edisi II. Graha ilmu. Yogyakarta. 
Shazali, S. S., Shamsudin, Z. H., \& Yunus, M. M. (2019). Instagram: A platform to develop student's writing ability. International journal ofacademic research in business and social sciences, 9 (1), 88-98.

Shepard, L. (2001). The role of classroom assessment in teaching and learning.

Tongco, M. D. C. (2007). Purposive sampling asa tool for informant selection. Ethnobotany research and applications, 5, 147-158.

Travers, John P. (1970). Fundamental of educational psychology.Scrantom, pensylvania: International textbook company.

Yuniati, D. (2015). The effectiveness of picture word inductive model (PWIM) for teaching writing recount text (an experimental research at the eighth grade students of Smp Negeri 1 Mrebet in the academic year 2014/2015).Doctoral dissertation, Universitas Muhammadiyah Purwokerto.

Yunus, N. A. (1981). Preparing and using aids for English language. Kuala Lumpur. 